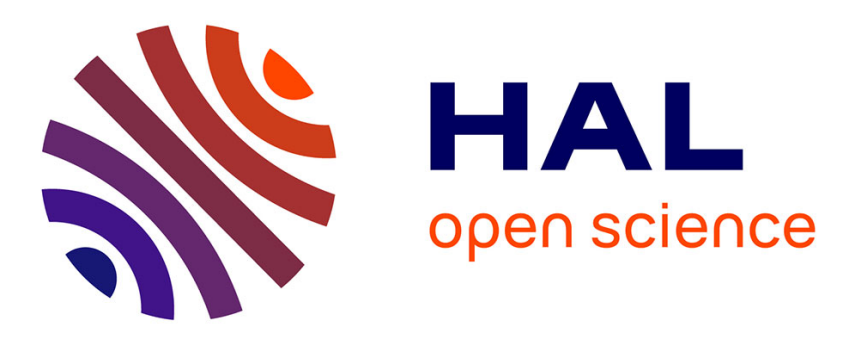

\title{
High-Order Sliding Mode Control of a Marine Current Turbine Driven Doubly-Fed Induction Generator
}

Seifeddine Benelghali, Mohamed Benbouzid, Tarek Ahmed-Ali, Jean Frédéric

Charpentier

\section{- To cite this version:}

Seifeddine Benelghali, Mohamed Benbouzid, Tarek Ahmed-Ali, Jean Frédéric Charpentier. HighOrder Sliding Mode Control of a Marine Current Turbine Driven Doubly-Fed Induction Generator. IEEE Journal of Oceanic Engineering, 2010, 35 (2), pp.402-411. 10.1109/JOE.2010.2040402 . hal00525410

\author{
HAL Id: hal-00525410 \\ https://hal.science/hal-00525410
}

Submitted on 11 Oct 2010

HAL is a multi-disciplinary open access archive for the deposit and dissemination of scientific research documents, whether they are published or not. The documents may come from teaching and research institutions in France or abroad, or from public or private research centers.
L'archive ouverte pluridisciplinaire HAL, est destinée au dépôt et à la diffusion de documents scientifiques de niveau recherche, publiés ou non, émanant des établissements d'enseignement et de recherche français ou étrangers, des laboratoires publics ou privés. 


\title{
Peer-Reviewed Technical Communication
}

\section{High-Order Sliding Mode Control of a Marine Current Turbine Driven Doubly-Fed Induction Generator}

\author{
Seif Eddine Ben Elghali, Student Member, IEEE, Mohamed El Hachemi Benbouzid, Senior Member, IEEE, \\ Tarek Ahmed-Ali, and Jean Frédéric Charpentier, Member, IEEE
}

\begin{abstract}
This paper deals with the speed control of a variable speed doubly-fed induction generator (DFIG)-based marine current turbine (MCT). To increase the generated power and therefore the efficiency of an MCT, a nonlinear controller has been proposed. DFIG has been already considered for similar applications, particularly wind turbine systems using mainly proportional-integral (PI) controllers. However, such kinds of controllers do not adequately handle some tidal resource characteristics such as turbulence and swell effects. These may decrease MCT performances. Moreover, DFIG parameter variations should be accounted for. Therefore, a robust nonlinear control strategy, namely high-order sliding mode (HOSM) control, is proposed. This control strategy relies on the resource and the marine turbine models that were validated by experimental data. The sensitivity of the proposed control strategy is analyzed regarding the swell effect as it is considered as the most disturbing one for the resource model. Tidal current data from the Raz de Sein (Brittany, France) are used to run simulations of a $7.5-\mathrm{kW}$ prototype over various flow regimes. Simulation results are presented and fully analyzed.
\end{abstract}

Index Terms-Doubly-fed induction generator (DFIG), high-order sliding mode (HOSM), marine current turbine (MCT), modeling, nonlinear control.

\section{NOMENCLATURE}

DFIG Doubly-fed induction generator.

MCT Marine current turbine.

HOSM High-order sliding mode.

Manuscript received March 17, 2009; revised November 25, 2009; accepted December 06, 2009. Date of publication April 26, 2010; date of current version May 26, 2010. This work was supported by Brest Métropole Océane (BMO), the European Social Fund (ESF), and the GDR SEEDS CNRS 2994 under the Internal Project HYDROLE. This work was done within the framework of the Marine Renewable Energy Commission of the Brittany Maritime Cluster (Pôle Mer Bretagne).

Associate Editor: H. Maeda.

S. E. Ben Elghali was with the University of Brest, EA 4325 LBMS, 29238 Brest Cedex 03, France. He is now with the French Naval Academy, Brest 29240, France (e-mail: seifeddine.ben_elghali@ecole-navale.fr).

M. E. H. Benbouzid is with the University of Brest, EA 4325 LBMS, 29238 Brest Cedex 03, France (e-mail: m.benbouzid@ieee.org).

T. Ahmed-Ali is with the University of Caen, UMR CNRS 6072 GREYC, 14032 Caen Cedex, France (e-mail: Tarek.Ahmed-Ali@greyc.ensicaen.fr).

J. F. Charpentier is with the French Naval Academy Research Institute (IRENav EA 3634), French Naval Academy, 29240 Brest Cedex 9, France (e-mail: charpentier@ecole-navale.fr).

Color versions of one or more of the figures in this paper are available online at http://ieeexplore.iee.org.

Digital Object Identifier 10.1109/JOE.2010.2040402

$\begin{array}{ll}\rho & \text { Fluid density. } \\ A & \text { Cross-sectional area of the marine turbine. } \\ V_{\text {tide }} & \text { Fluid speed. } \\ C_{p} & \text { Power coefficient. } \\ C & \text { Tide coefficient. } \\ V_{s t}\left(V_{n t}\right) & \text { Spring (neap) tide current speed. } \\ s,(r) & \text { Stator (rotor) index. } \\ d, q & \text { Synchronous reference frame index. } \\ V(I) & \text { Voltage (current). } \\ P(Q) & \text { Active (reactive) power. } \\ \phi & \text { Flux. } \\ T_{e m}\left(T_{m}\right) & \text { Electromagnetic torque (mechanical torque). } \\ R & \text { Resistance. } \\ L(M) & \text { Inductance (mutual inductance). } \\ \theta_{r} & \text { Rotor position. } \\ \omega_{r}\left(\omega_{s}\right) & \text { Angular speed (synchronous speed). } \\ f & \text { Viscosity coefficient. } \\ J & \text { Rotor inertia. } \\ p & \text { Pole pair number. } \\ & \end{array}$

\section{INTRODUCTION}

O NLY a fraction of the global ocean energy resource is to be found in sites which are economically feasible to explore with available technology. However, this fraction could still make a considerable contribution to the electricity supply. This is the reason why the marine renewable sector is currently the focus of much industrial and academic research around the world [1]. Sites with attractive wave climate and intense tidal currents are abundant near the European coastline. It has been shown that $48 \%$ of the European tidal resource is in the United Kingdom, $42 \%$ in France, and $8 \%$ in Ireland. Three examples in France are shown in Fig. 1. The Raz Blanchard situated in Cap de la Hague experiences extreme tidal currents exceeding $8 \mathrm{kn}$ and leading to a large amount of kinetic energy flux. 


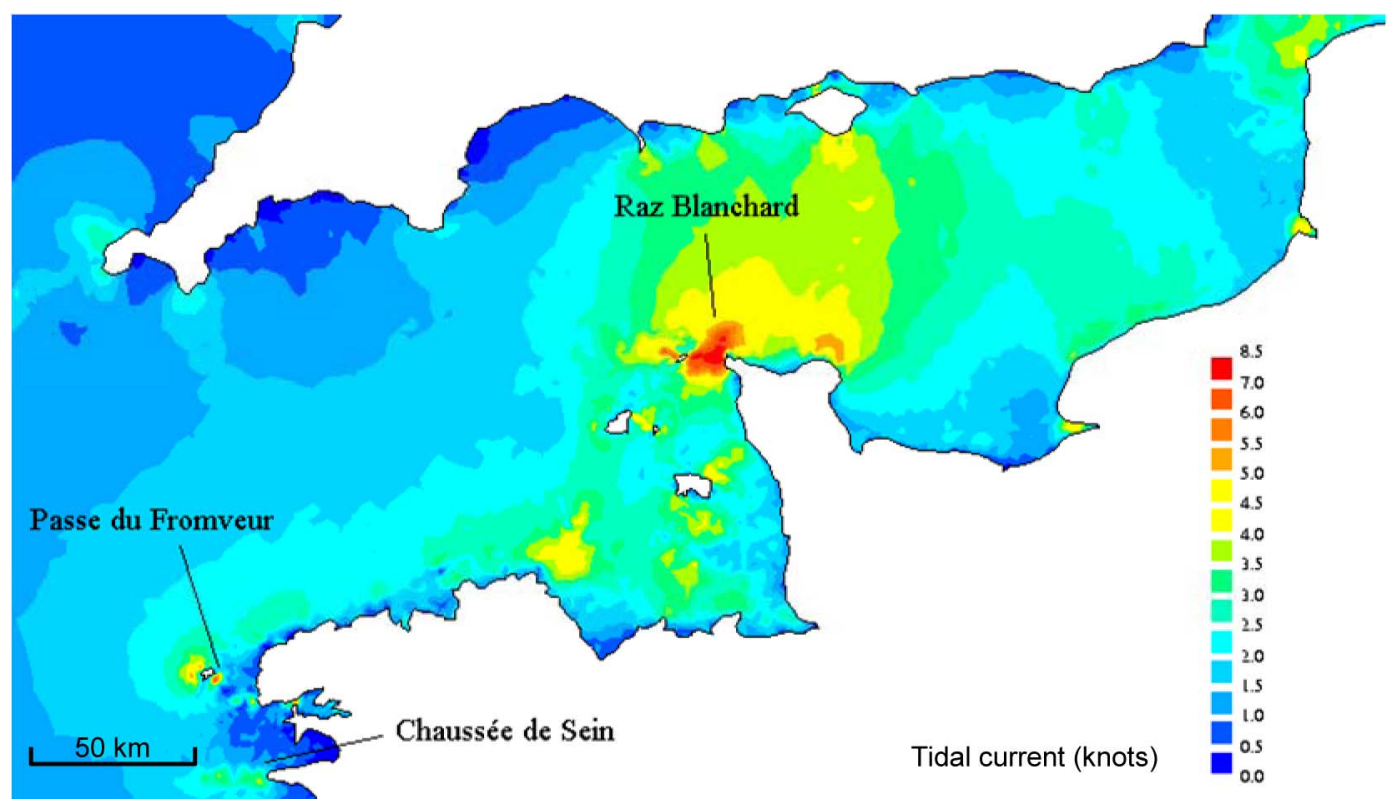

Fig. 1. Raz Blanchard, Fromveur, and Raz de Sein sites on the French western coast.

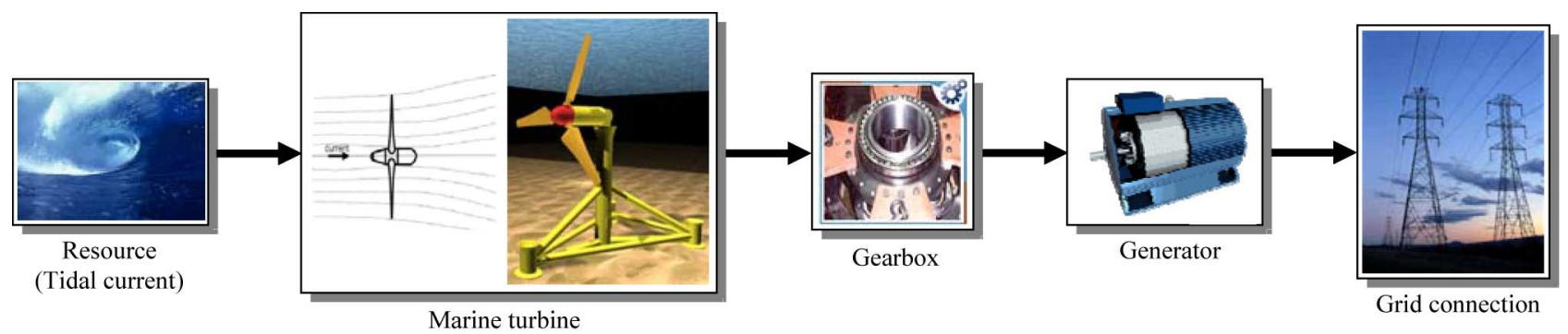

Fig. 2. Marine current turbine global scheme.

There are basically two ways of generating electricity from marine and tidal currents: by building a tidal barrage across an estuary or a bay in high tide areas, or by extracting energy from free flowing water (tidal kinetic energy). Within the last few decades, developers have shifted towards technologies that capture tidally driven coastal currents or tidal stream [2]. The astronomic nature of this resource makes it predictable, to within $98 \%$ accuracy for decades, and independent of prevailing weather conditions. This predictability is critical to a successful integration of renewable energy in the electrical grid [3]. Therefore, it is obvious that there is a need to quantify the potential for generating electricity from these various sites [4].

In this context, this paper is dealing with the control of a DFIG-based MCT. It should be noted that when scanning the literature, one will find very few papers on this topic [5]. Therefore, to account for some of tidal resource characteristics such as turbulence and swell effects, and the DFIG parameter variation, a robust nonlinear control strategy, namely HOSM control, is proposed. This control strategy relies on the resource and the marine turbine models that were validated by experimental data. Tidal current data from the Raz de Sein (Brittany, France) are used to run simulations of a $7.5-\mathrm{kW}$ prototype over various flow regimes [6].

\section{MARine CuRrent Turbine Modeling}

The global scheme for a grid-connected marine current turbine is composed of different block diagrams: the resource, the hydrodynamics, the gearbox, the generator, and the grid connection models (Fig. 2).

\section{A. The Resource Model}

1) Resource Potential: The total kinetic power in an MCT has a similar dependence to that of a wind turbine and is governed by the following equation [7], [8]:

$$
P=\frac{1}{2} \rho A V_{\text {tide }}^{3} \text {. }
$$

However, a marine energy turbine can only harness a fraction of this power due to losses and (1) is modified as follows:

$$
P=\frac{1}{2} \rho C_{p} A V_{\text {tide }}^{3} \text {. }
$$

For marine turbines, $C_{p}$ is estimated to be in the range $0.35-0.5[9]$. 


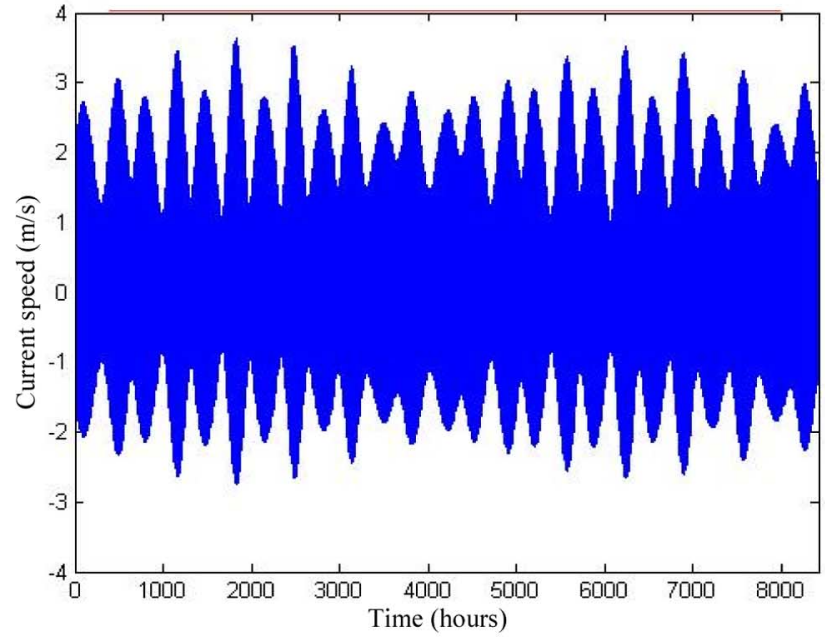

(a)

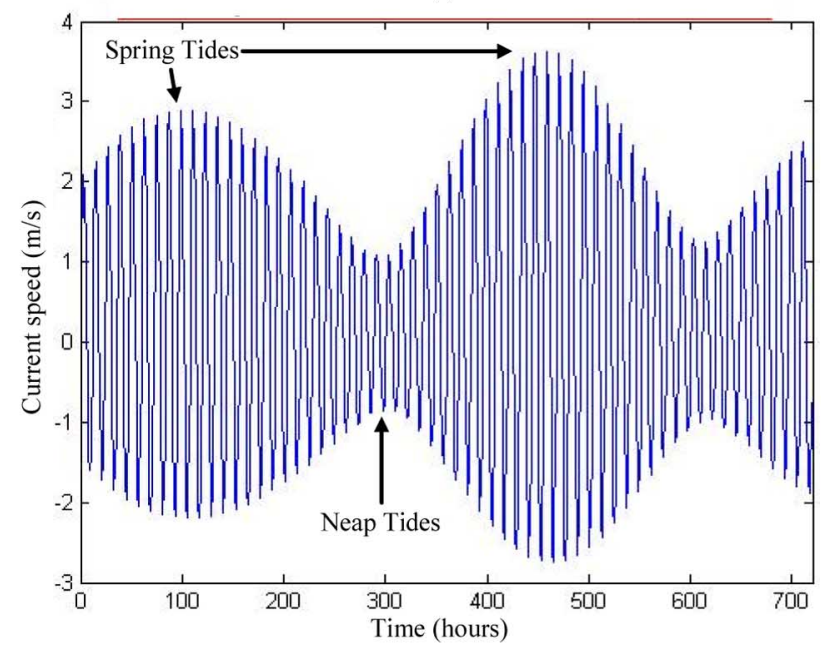

(b)

Fig. 3. Tidal speed in the Raz de Sein for (a) year 2007, and (b) March 2007.

2) Resource Model: Tidal current data are given by the SHOM (French Navy Hydrographic and Oceanographic Service, Brest, France) and are available for various locations in chart form. The available SHOM charts give, for a specific site, the current speeds for spring and neap tides. These values are given at hourly intervals starting at $6 \mathrm{~h}$ before high waters and ending $6 \mathrm{~h}$ after. Therefore, knowing tides coefficient, it is easy to derive a simple and practical model for tidal current speeds $V_{\text {tide }}$

$$
V_{\text {tide }}=V_{n t}+\frac{(C-45)\left(V_{s t}-V_{n t}\right)}{95-45} .
$$

where 95 and 45 are the spring and neap tide medium coefficients, respectively.

This first-order model is then used to calculate the tidal speed each hour. The implemented model will allow the user to compute tidal speeds in a predefined time range. Fig. 3 shows the model output for a month (March 2007) and for a year (2007).
This adopted resource model has several advantages including its modularity and its simplicity. Indeed, the marine turbine site can be changed, the useful current speed can be adapted, and the time range taken into account can also be adapted from one month to one year.

\section{B. The Turbine Rotor Model}

The harnessing of the energy in a tidal flow requires the conversion of kinetic energy in a moving fluid, in this case water, into the motion of a mechanical system, which can then drive a generator. Therefore, it is not too surprising that many developers suggest using technology that mirrors that which has been successfully utilized to harness the wind, which is also a moving fluid [2]. Moreover, much of the technology is based upon the use of horizontal axis turbines. Therefore, much can be transferred from the modeling and operation of wind turbines [10]. However, there are a number of fundamental differences in the design and operation of marine turbines. Particular differences entail changes in force loadings, immersion depth, different stall characteristics, and the possible occurrence of cavitation [11], [12].

Turbine rotor aerodynamics refers to the interaction of the wind turbine rotor with the incoming wind. The treatment of rotor aerodynamics in all current design codes is based on Glauert's well-known and well-established blade element momentum (BEM) theory [13]. Therefore, the BEM method has been used for the marine turbine rotor modeling. Indeed, it is widely used in the industry as a computational tool to predict aerodynamic loads and power of turbine rotors. It is relatively simple and computationally fast, meeting the requirements of accuracy and control loop computational speed.

\section{The Generator Model}

The generator chosen for the marine current system was the DFIG [14]. DFIG-based marine turbines, as for wind turbines, will offer several advantages including variable speed operation, and four-quadrant active and reactive power capabilities. The main merit of the DFIG is its capability to deliver constant voltage and frequency output for $\pm 30 \%$ speed variation around conventional synchronous speed. It can be noticed that another choice for the speed variation range is possible (between $30 \%$ and $50 \%$ is more often used). This $30 \%$ variation speed choice is directly related to a low-power sizing of the rotor converter. Therefore, the rotor speed reference generated by the MPPT strategy was limited at $\pm 30 \%$ of the conventional synchronous speed. Then, such system results in lower converter costs and lower power losses compared to a system based on a fully fed synchronous generator with full-rated converter. Moreover, a DFIG is robust and requires little maintenance [5], [15]. A schematic diagram of a DFIG-based generation system is shown in Fig. 4. This figure describes the DFIG-based MCT system main components: the mechanical part (turbine, gear, pitch drive) and the doubly-fed induction generator which may exchange power with the grid not only through the stator but also through the rotor. 


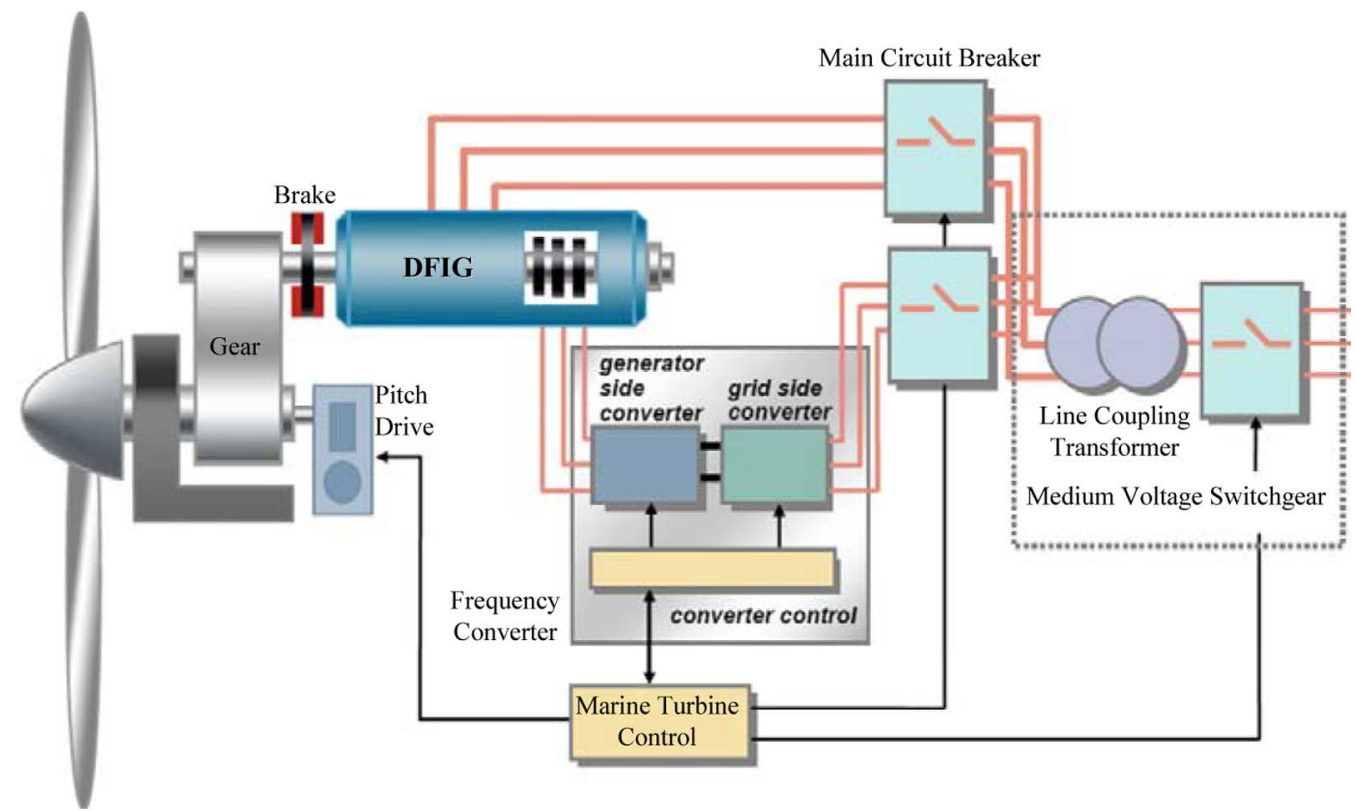

Fig. 4. Schematic diagram of a DFIG-based generation system.

The control system is usually defined in the synchronous $d-q$ frame fixed to either the stator voltage or the stator flux [14]. For the proposed control strategy, the generator dynamic model written in a synchronously rotating frame $d-q$ is given by

$$
\left\{\begin{array}{l}
\frac{d \phi_{d s}}{d t}=V_{d s}+R_{s} I_{d s}+\omega_{s} \phi_{q s} \\
\frac{d \phi_{q s}}{d t}=V_{q s}+R_{s} I_{q s}-\omega_{s} \phi_{d s} \\
\frac{d \phi_{d r}}{d t}=V_{d r}+R_{r} I_{d r}+\omega_{r} \phi_{q r} \\
\frac{d \phi_{q r}}{d t}=V_{q r}+R_{r} I_{q r}-\omega_{r} \phi_{d r} \\
\phi_{d s}=-L_{s} I_{d s}-M I_{d s} \\
\phi_{q s}=-L_{s} I_{q s}-M I_{q r} \\
\phi_{d r}=-L_{r} I_{d r}-M I_{d s} \\
\phi_{q r}=-L_{r} I_{q r}-M I_{q s} \\
T_{e m}=p M\left(I_{q s} I_{d r}-I_{d s} I_{q r}\right) \\
J \frac{d \omega}{d t}=T_{e m}-T_{m}-f \omega .
\end{array}\right.
$$

\section{The VARiable SPeEd CONTROL Strategy}

\section{A. Problem Formulation}

A common practice in addressing DFIG control problem is to use a linearization approach [16]-[22]. However, due to the tidal resource characteristics such as turbulence and swell effects, and the inevitable uncertainties inherent in DFIG-based MCTs, such control methods come at the price of poor system performance and low reliability [23], hence the need for nonlinear and robust control to take into account these control problems [24], [25].

In this context, sliding mode control seems to be an interesting approach. Indeed, it is one of the effective nonlinear robust control approaches since it provides system dynamics with an invariant property to uncertainties once the system dynamics are controlled in the sliding mode [26]. Moreover, it is easy to implement.

For DFIG-based MCTs, sliding mode should provide a suitable control tool for conversion efficiency, torque oscillation smoothing [27], and robustness against electric grid disturbances [28]. Indeed, in a previous study, proportional-integral (PI) control has been adopted for speed tracking of DFIG-based MCT [29]. This kind of controller is well known for its robustness and its simplicity for constant references. Its gains are computed by compensating the larger system time constant and by guaranteeing a constant tracking error when the reference is a ramp. However, in case of MCT, the generated reference signals are time varying and the current sources may be turbulent, which makes the PI feedback not efficient.

\section{B. Why High-Order Sliding Mode?}

Sliding mode control laws for nonlinear systems have been widely investigated and developed since they were introduced in [30]. The objective of this method is, by means of a discontinuous control, to constrain the system to evolve and stay, after a finite time, on a sliding manifold where the resulting behavior has some prescribed dynamics. Sliding mode control exhibits relative simplicity of design and robustness properties with respect to matched perturbations. However, some problems exist such as the chattering phenomenon (high-frequency oscillations along the sliding motion). This drawback can be very harmful to the generator since the discontinuous control can cause overheating of the coils and excite some unmodeled high-frequency dynamics.

To avoid chattering some approaches were proposed [31]. The main idea was to change the dynamics in close proximity to the discontinuity surface to avoid real discontinuity and at the same time to preserve the main properties of the whole system. However, the ultimate accuracy and robustness of the sliding mode were partially lost. Recently introduced, HOSMs generalize the basic sliding mode idea that acts on the high-order time 


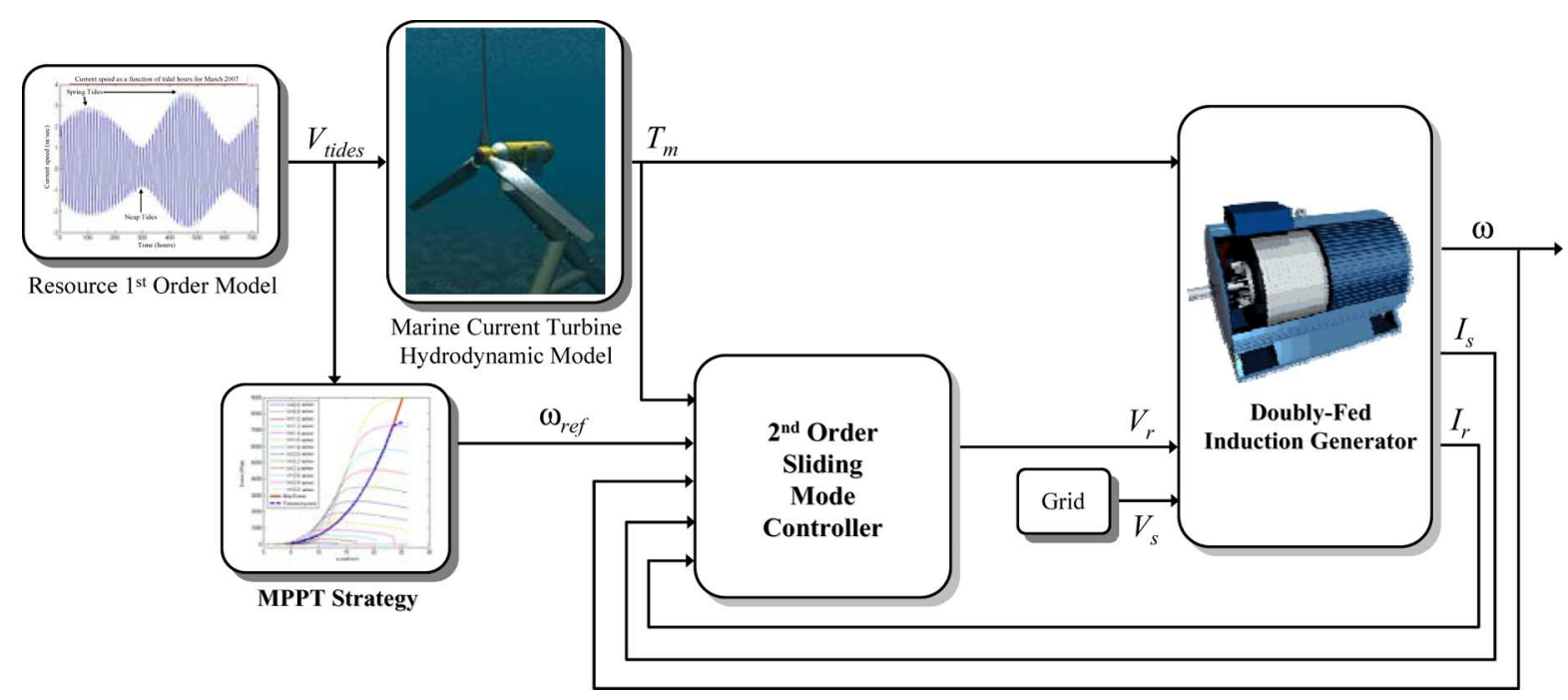

Fig. 5. Proposed control scheme.

derivatives of the system deviation from the constraint instead of influencing the first deviation derivative as it happens in standard sliding modes. Along with keeping the main advantages of the original approach, they deal with the chattering effect and provide for even higher accuracy in realization. A number of such controllers were described in the literature [32], [33].

\section{The Proposed Control Strategy}

The proposed control strategy is based on a step-by-step procedure. First, the speed reference $\omega_{\text {ref }}$ is generated by a maximum power point tracking (MPPT) strategy [34]. Then, an optimal electromagnetic torque, which ensures the rotor speed convergences to $\omega_{\text {ref }}$ is computed using the following mechanical equation:

$$
T_{\text {em_ref }}=T_{m}+f \omega-\alpha\left(\omega-\omega_{\text {ref }}\right)+J \dot{\omega}_{\text {ref }}
$$

where $\alpha$ is a positive constant. Afterwards, rotor current references are derived to ensure the DFIG torque and reactive power convergence to the optimal torque and zero, respectively

$$
\left\{\begin{array}{l}
I_{q r_{\text {_ref }}}=-\frac{L_{s}}{p M} \frac{T_{e m_{\text {_ref }}}}{\phi_{s d}} \\
I_{d r_{\text {_ref }}}=\frac{1}{M} \phi_{s d} .
\end{array}\right.
$$

To ensure the rotor currents convergence to their references, a robust HOSM strategy is used [32]. Let us define the following surfaces:

$$
\left\{\begin{array}{l}
S_{1}=I_{d r}-I_{d r_{\text {ref }}} \\
S_{2}=I_{q r}-I_{q r_{-} \text {ref }}
\end{array}\right.
$$

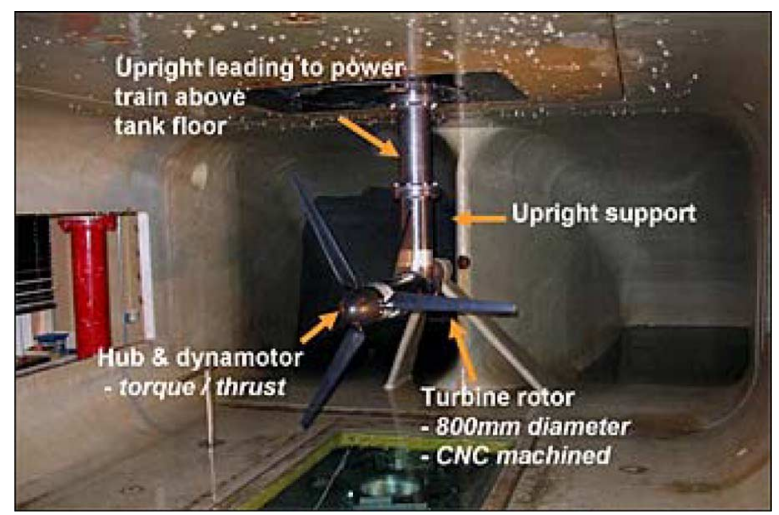

Fig. 6. Photograph of the tested marine turbine [37], [38].

Then, we have (8) and (9), shown at the bottom of the page, where $\varphi_{1}(t, x), \varphi_{2}(t, x), \gamma_{1}(t, x)$, and $\gamma_{2}(t, x)$ are uncertain functions which satisfy

$$
\left\{\begin{array}{l}
\varphi_{1}>0,\left|\varphi_{1}\right|>\Phi_{1}, 0<\Gamma_{m 1}<\gamma_{1}<\Gamma_{M 1} \\
\varphi_{2}>0,\left|\varphi_{2}\right|>\Phi_{2}, 0<\Gamma_{m 2}<\gamma_{2}<\Gamma_{M 2}
\end{array}\right.
$$

The proposed control approach which is based on the super twisting algorithm has been introduced by Levant [33]. The proposed high-order (second) sliding mode controller contains two parts

$$
V_{d r}=u_{1}+u_{2}
$$

where

$$
\left\{\begin{array}{l}
\dot{u}_{1}=-\alpha_{1} \operatorname{sign}\left(S_{1}\right) \\
u_{2}=-\beta_{1}\left|S_{1}\right|^{\rho} \operatorname{sign}\left(S_{1}\right)
\end{array}\right.
$$

$$
\begin{aligned}
& \left\{\begin{array}{l}
\dot{S}_{1}=\frac{L_{s}}{M^{2}-L_{r} L_{s}}\left(V_{d r}+R_{r} I_{d r}-\omega_{r}\left(L_{r} I_{q r}+M I_{q s}\right)-\frac{M}{L_{s}} V_{d s}-\frac{M R_{s}}{L_{s}} I_{d s}+\frac{M}{L_{s}} \omega_{s}\left(L_{s} I_{q s}+M I_{q r}\right)\right)-\dot{I}_{d r \_ \text {ref }} \\
\ddot{S}_{1}=\varphi_{1}(t, x)+\gamma_{1}(t, x) \dot{V}_{d r}
\end{array}\right. \\
& \left\{\begin{array}{l}
\dot{S}_{2}=\frac{L_{s}}{M^{2}-L_{r} L_{s}}\left(V_{q r}+R_{r} I_{q r}+\omega_{r}\left(L_{r} I_{d r}+M I_{d s}\right)-\frac{M}{L_{s}} V_{q s}-\frac{M R_{s}}{L_{s}} I_{q s}-\frac{M}{L_{s}} \omega_{s}\left(L_{s} I_{d s}+M I_{d r}\right)\right)-\dot{I}_{q r_{-} \text {ref }} \\
\ddot{S}_{2}=\varphi_{2}(t, x)+\gamma_{2}(t, x) \dot{V}_{q r}
\end{array}\right.
\end{aligned}
$$




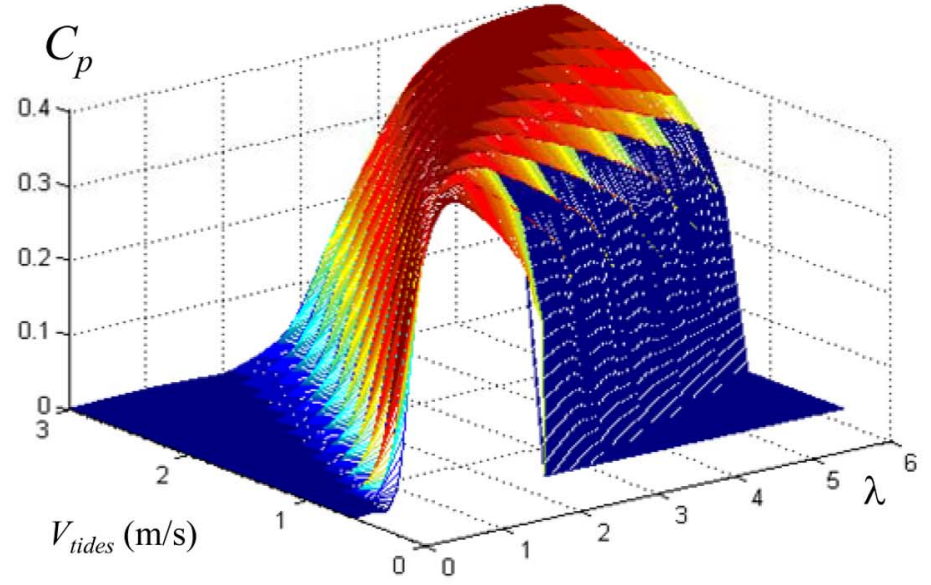

(a)

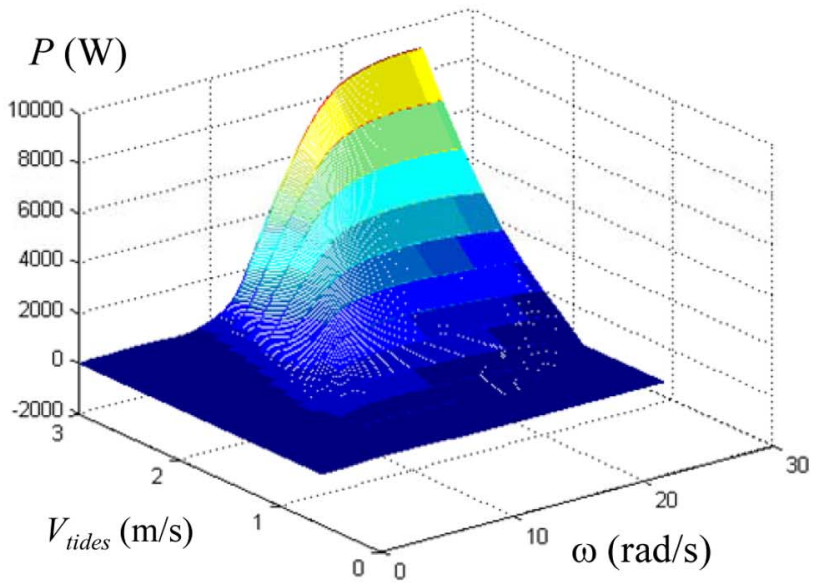

(b)

Fig. 7. (a) $C_{p}\left(\lambda, V_{\text {tides }}\right)$ curves. (b) The extractable power $P\left(\omega, V_{\text {tides }}\right)$.

and

$$
V_{q r}=w_{1}+w_{2}
$$

where

$$
\left\{\begin{array}{l}
\dot{w}_{1}=-\alpha_{2} \operatorname{sign}\left(S_{2}\right) \\
w_{2}=-\beta_{2}\left|S_{2}\right|^{\rho} \operatorname{sign}\left(S_{2}\right) .
\end{array}\right.
$$

To ensure the convergence of the sliding manifolds to zero in finite time, the gains can be chosen as follows [32], [35]:

$$
\left\{\begin{array}{l}
\alpha_{i}>\frac{\Phi_{i}}{\Gamma_{m i}} \\
\beta_{i}^{2} \geq \frac{4 \Phi_{i}}{\Gamma_{m i}^{2}} \frac{\Gamma_{M i}\left(\alpha_{i}+\Phi_{i}\right)}{\Gamma_{m i}\left(\alpha_{i}-\Phi_{i}\right)}, \quad i=1,2 \\
0<\rho \leq 0.5
\end{array}\right.
$$

The above proposed high-order sliding mode control strategy for a DFIG-based MCT is illustrated in Fig. 5. In this figure, the MCT model is symbolized by the resource, the hydrodynamics, the DFIG, and the grid blocks. Moreover, Fig. 5 highlights the fact that the MPPT strategy generates the speed reference for the second-order sliding mode controller.

\section{VALIDATION RESULTS}

\section{A. Validation Data and Parameters}

In this work, the Raz de Sein site was chosen above several others listed in the European Commission report EUR16683 [36] due to the presence of high-speed current coupled with appropriate depths suitable for marine turbines. Moreover, the marine current speed distribution for most of the time is greater than the minimum, estimated to be $1 \mathrm{~m} / \mathrm{s}$, required for economic deployment of marine turbines [4].

The turbine rotor model was validated through the comparison of the simulation model with experimental data from the available literature [37], [38] (Fig. 6). This figure shows the tested marine turbine which has a $1.44-\mathrm{m}$ diameter and is 7.5 $\mathrm{kW}$. The adopted MCT is of $1.44-\mathrm{m}$ diameter and $7.5 \mathrm{~kW}$.

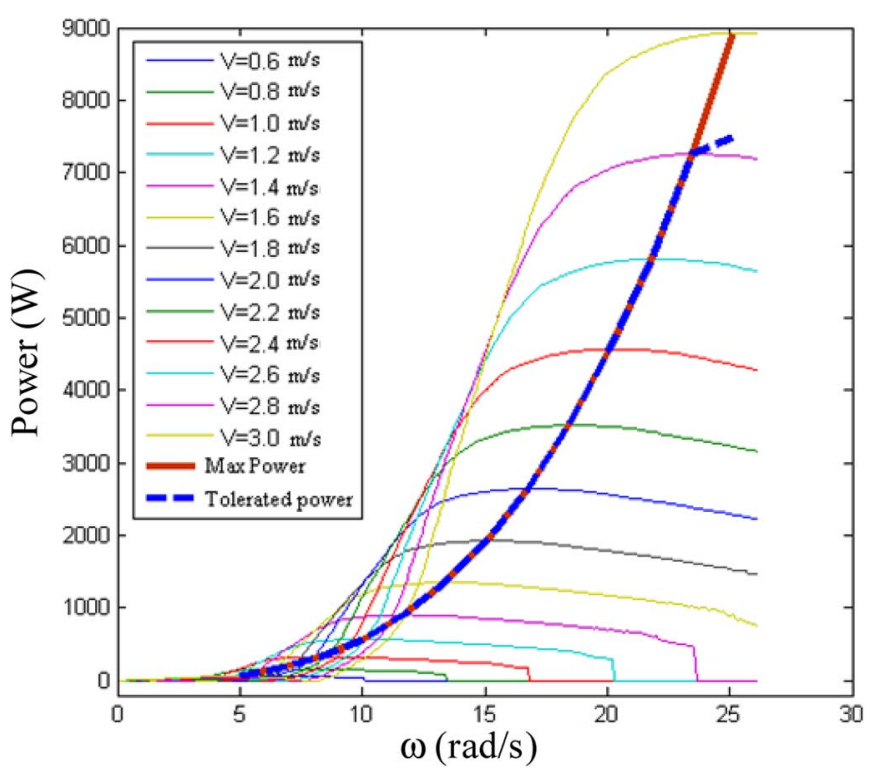

Fig. 8. Power curves for different tidal current speed.

In this context, the obtained power coefficient $C_{p}$ and the extractable power curves are shown in Fig. 7.

The 7.5-kW DFIG parameters are given in the Appendix.

\section{B. Validation Results for a Filtered Resource}

For speed references given by Fig. 8 (MPPT) and a filtered resource (filtered $V_{\text {tides }}$ ) given by Fig. 9, the DFIG-based MCT control performances are shown in Figs. 10 and 11, respectively, illustrating the rotor speed tracking performance and the generated active power.

The obtained results show good tracking performances of the DFIG rotor speed: the reactive and the generated active power. Based on results in [29] and as expected, the generated active power tracking is greatly improved. However, these performances have to be slightly improved using a power control loop. 


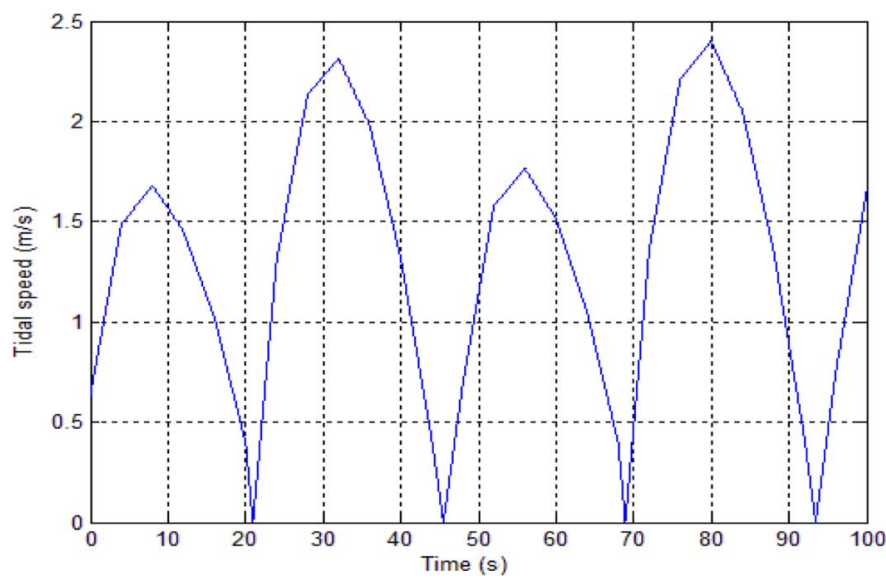

Fig. 9. Filtered resource speed.

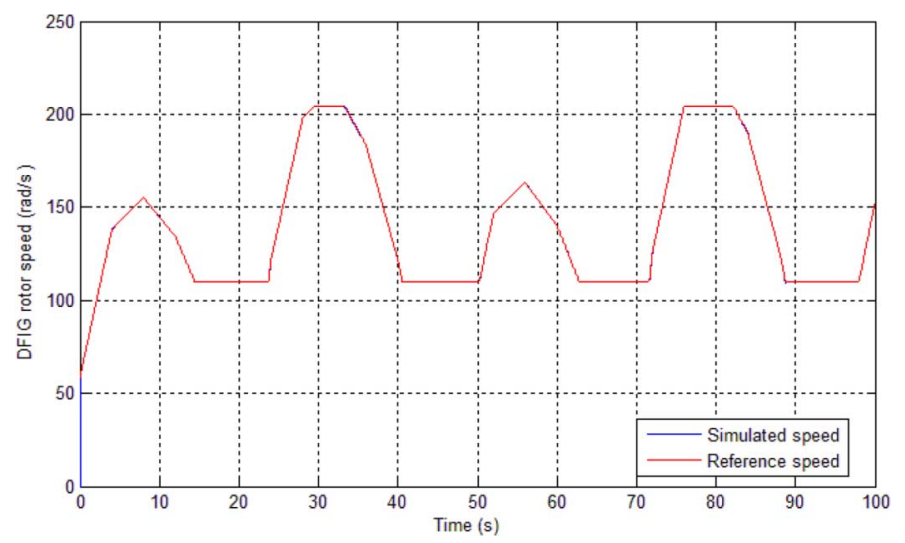

Fig. 10. DFIG rotor speed and its reference.

\section{Validation Results for a Turbulent Resource}

Since the swell effect is considered as the most disturbing one for our resource model, a swell Stoke model is added. In this case, the speed potential is given by

$$
\left\{\begin{array}{l}
V_{\text {tides }}=\operatorname{grad} \phi \\
\phi=-\frac{H L}{2 T} \frac{\operatorname{ch}\left(2 \Pi\left(\frac{z+d}{L}\right)\right)}{\operatorname{sh}\left(2 \Pi\left(\frac{d}{L}\right)\right)} \sin \left(2 \Pi\left(\frac{t}{T}-\frac{x}{L}\right)\right) .
\end{array}\right.
$$

where the swell characteristics are illustrated in Fig. 12.

The turbulent resource characteristics are obtained by adding the swell effect to the first-order model of the predicted resource (Fig. 13). In this case, the DFIG-based MCT control performances are shown in Figs. 14 and 15, respectively, illustrating the rotor speed tracking performance and the generated active power. In spite of high turbulences, Fig. 14 shows a good tracking accuracy of the high-order sliding mode control. However, the generated power exhibits fluctuations (Fig. 15). In fact, these fluctuations are mainly due to accelerations and decelerations imposed on the marine current turbine by the MPPT strategy for a turbulent resource. This problem could be simply solved by filtering the resource at a certain level to avoid losing useful powers.

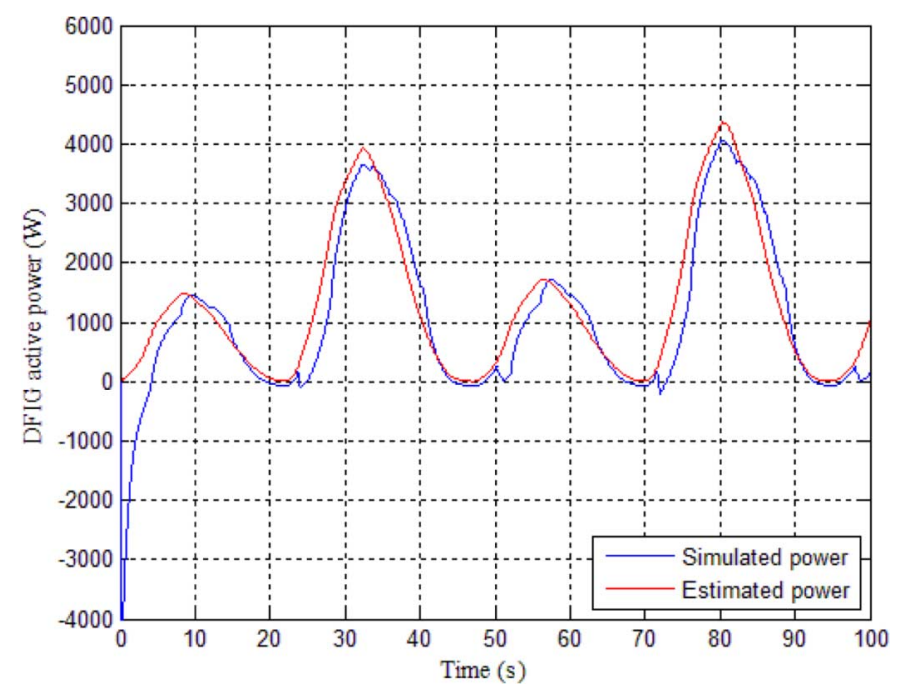

Fig. 11. DFIG generated active power.

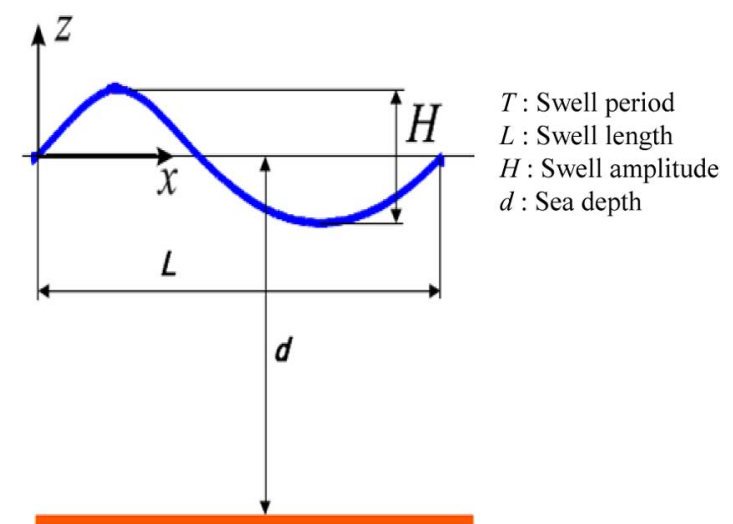

Fig. 12. Swell characteristics.

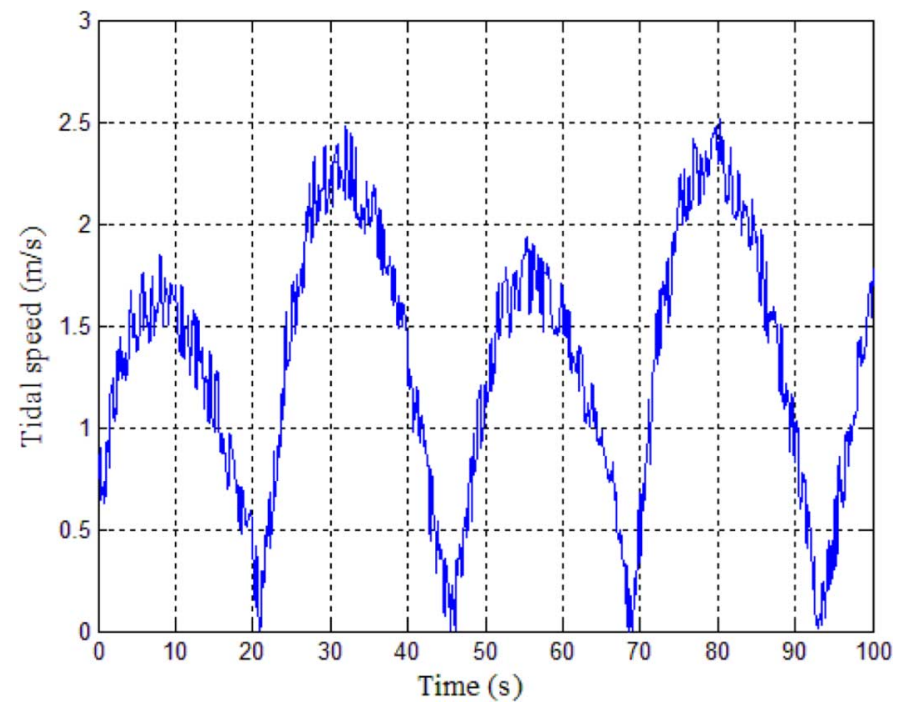

Fig. 13. Turbulent resource speed.

\section{Discussions}

The DFIG rotor speed and the generated active power may experience high peaks at $t=0$. These peaks are due to the initial value of the used integral blocs in Matlab/Simulink ${ }^{\circledR}$. To overcome this problem, the MCT connection to the DFIG has been delayed a few seconds (Figs. 11 and 15). This will be helpful in future experiments. Moreover, these figures may 
TABLE I

DFIG-BASED MCT SIMULATED CASES

\begin{tabular}{|c|c|c|c|}
\hline \multirow{2}{*}{ Case } & \multirow{2}{*}{ Simulation Conditions / Tidal speed $(\mathrm{m} / \mathrm{s})$} & \multicolumn{2}{|c|}{$\begin{array}{l}\text { Average Power } \\
\qquad(\mathrm{kW})\end{array}$} \\
\hline & & PI & HOSM \\
\hline 1 & $\begin{array}{l}V_{\text {real }}=2 \\
V_{\text {ref }}=2\end{array}$ & 2.518 & 2.483 \\
\hline 2 & $\begin{array}{l}V_{\text {real }}=2+0.3252 \cos (0.4189 t)+0.2749 \cos (0.6283 t) \\
V_{\text {ref }}=2+0.3252 \cos (0.4189 t)+0.2749 \cos (0.6283 t)\end{array}$ & 2.694 & 2.565 \\
\hline 3 & $\begin{array}{l}V_{\text {real }}=2+0.3252 \cos (0.4189 t)+0.2749 \cos (0.6283 t) \\
V_{\text {ref }}=2\end{array}$ & 2.449 & 2.676 \\
\hline 4 & $\begin{array}{l}V_{\text {real }}=2+0.3252 \cos (0.4189 t)+0.2749 \cos (0.6283 t)+b(t) \\
V_{\text {ref }}=2\end{array}$ & 2.397 & 2.631 \\
\hline 5 & $\begin{array}{l}V_{\text {real }}=2+0.3252 \cos (0.4189 t)+0.2749 \cos (0.6283 t)+b(t) \\
V_{\text {ref }}=2+0.3252 \cos (0.4189 t)+0.2749 \cos (0.6283 t)\end{array}$ & 2.573 & 2.788 \\
\hline
\end{tabular}

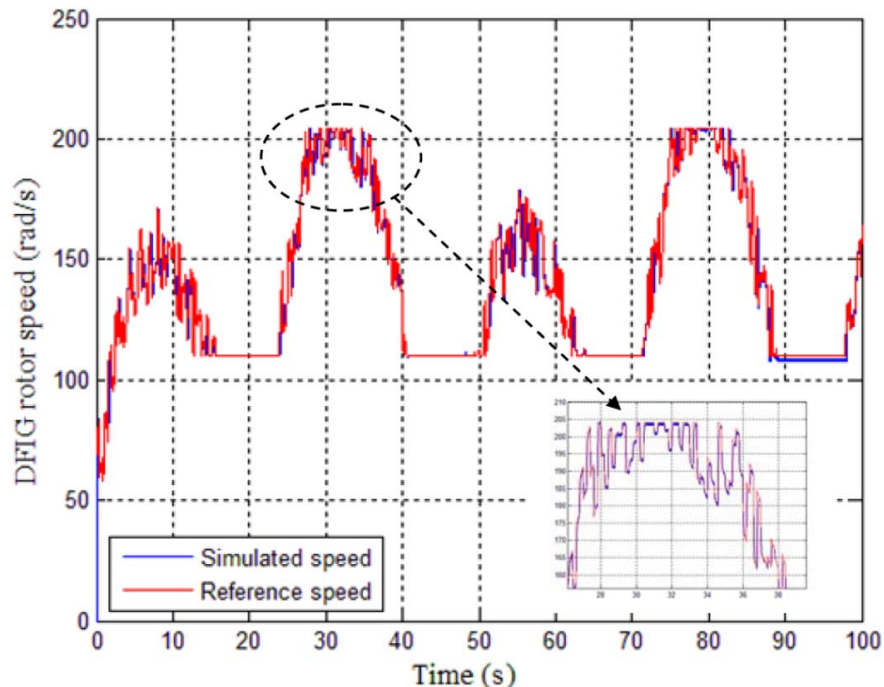

Fig. 14. DFIG rotor speed and its reference.

also exhibit a number of short peaks. These peaks are due to the Matlab/Simulink ${ }^{\circledR}$ solver configuration and are not due to the DFIG-based MCT model. Indeed, by reducing the sampling time those peaks will disappear but the simulation time will increase.

\section{E. Comparisons With Classical PI Control}

Hereafter, a comparison between the PI and the HOSM control strategies is carried out through different case studies for the DFIG-based MCT [29]. This comparison will also allow the

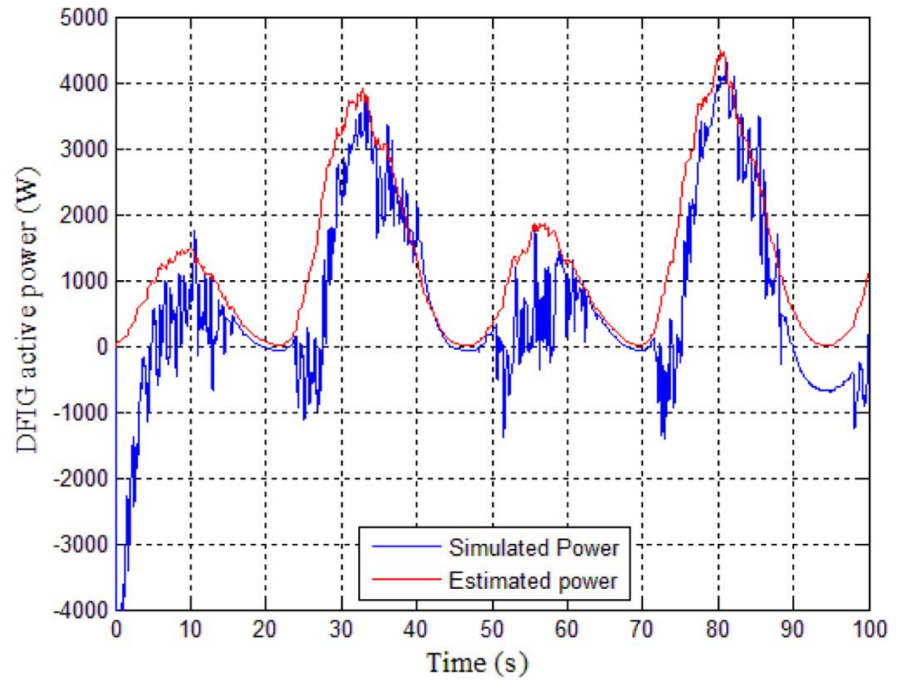

Fig. 15. DFIG generated active power.

evaluation of the resource model and its impact on the generated power. Therefore, three types of resources taking into account external disturbance have been simulated in different cases summarized in Table I. In the considered cases, the comparison is mainly based on the tidal speed values $V_{\text {real }}$ and $V_{\text {ref }}$. Indeed, $V_{\text {real }}$ is the tidal speed used as an input for the MCT model. $V_{\text {ref }}$ is the value of the tidal speed used as in input for the MPPT strategies (Fig. 5).

The simulation time has been chosen to evaluate the influence of swell and sea surface effect disturbances which have 
time constants or periods of few seconds. In these conditions, the predicted average value of the tidal speed is assumed to be constant and equal to $2 \mathrm{~m} / \mathrm{s}$ (4 kn).

In the simulated cases, several waveforms for the tidal speed with and without disturbances have been considered. The three taken resource values are the kinetic speed, the swell disturbance, and a random signal $b(t)$ that represents all the other disturbances.

The simulated cases can be divided in two categories. The first one gathers cases 1 and 2, in which $V_{\text {real }}$ and $V_{\text {ref }}$ were set equal. Therefore, it is supposed that the tidal speed is well known. These cases give an idea about the performances of both control strategies in ideal operating conditions.

However, the second category gathers cases 3,4 , and 5 . These cases allow the use of the tidal predicted average speed as a reference for the MPPT calculations, and therefore, allow a sensorless control (no need for tidal speed sensor for the MCT). Through these simulations, the robustness of the control strategies was evaluated.

For all the simulations, PI and HOSM parameters are set in such a way that PI control performances are better than the HOSM ones in an ideal condition (cases 1 and 2). The obtained results prove that HOSM control is more adapted when the tidal speed is not well known (cases 3, 4, and 5). Indeed, in these three cases, it can be noted that the generated power is more important than those given by the PI control.

It should be noted that the average active power is limited under $3 \mathrm{~kW}$ due to the use of a small turbine (1.44-m diameter).

\section{CONCLUSION}

This paper dealt with an HOSM control of DFIG-based MCT. The variable speed control strategy relies on the resource and the marine turbine models that were validated by experimental data. Tidal current data from the Raz de Sein (Brittany, France) have been used to run simulations of a $7.5-\mathrm{kW}$ prototype over various flow regimes.

The obtained results are very encouraging. Indeed, simulation results have shown that the proposed control strategy is effective in terms of speed tracking and power regulation. In other words, it has been shown that the second-order sliding mode control seems to be a good candidate when the resource is not well known and even if the resource is heavily disturbed.

\section{APPENDIX}

\section{PARAMETERS OF THE USED DFIG}

$$
\begin{gathered}
R_{s}=0.455 \Omega, L_{s}=0.084 \mathrm{H}, R_{r}=0.62 \Omega, L_{r}=0.081 \mathrm{H}, \\
M=0.078 \mathrm{H}, J=0.3125 \mathrm{~kg} \cdot \mathrm{m}^{2}, f=6.7310^{-3} \mathrm{Nms}^{-1} .
\end{gathered}
$$

\section{REFERENCES}

[1] C. M. Johnstone, K. Nielsen, T. Lewis, A. Sarmento, and G. Lemonis, "EC FPVI co-ordinated action on ocean energy: A European platform ford sharing technical information and research outcomes in wave and tidal energy systems," Renewable Energy, vol. 31, pp. 191-196, 2006.

[2] S. E. Ben Elghali, M. E. H. Benbouzid, and J. F. Charpentier, "Marine tidal current electric power generation technology: State of the art and current status," in Proc. IEEE Int. Electr. Mach. Drives Conf., Antalya, Turkey, May 2007, vol. 2, pp. 1407-1412.
[3] P. Meisen and T. Hammons, "Harnessing the untapped energy potential of the oceans: Tidal, wave, currents and OTEC," in Proc. IEEE Power Eng. Soc. General Meeting Panel Session, San Francisco, CA, Jun. 2005, pp. 1853-1854.

[4] L. Myers and A. S. Bahaj, "Simulated electrical power potential harnessed by marine current turbine arrays in the Alderney race," Renewable Energy, vol. 30, no. 11, pp. 1713-1731, Sep. 2005.

[5] J. W. Park, K. W. Lee, and H. J. Lee, "Wide speed operation of a doubly-fed induction generator for tidal current energy," in Proc. IEEE Annu. Conf. Ind. Electron., Busan, South Korea, 2004, vol. 2, pp. $1333-1338$.

[6] S. E. Ben Elghali, M. E. H. Benbouzid, T. Ahmed-Ali, J. F. Charpentier, and F. Mekri, "High-order sliding mode control of DFIG-based marine current turbine," in Proc. IEEE Annu. Conf. Ind. Electron., Orlando, FL, Nov. 2008, pp. 1228-1233.

[7] S. J. Couch and I. Bryden, "Tidal current energy extraction: Hydrodynamic resource characteristics," Proc. IMechE M, J. Eng. Maritime, vol. 220, no. 4, pp. 185-194, 2006.

[8] A. S. Bahaj and L. E. Myers, "Fundamentals applicable to the utilisation of marine current turbines for energy production," Renewable Energy, vol. 28, no. 14, pp. 2205-2211, Nov. 2003.

[9] L. Myers and A. S. Bahaj, "Power output performance characteristics of a horizontal axis marine current turbine," Renewable Energy, vol. 31, no. 2, pp. 197-208, Feb. 2006.

[10] E. Bossanyi, Wind Energy Handbook. New York: Wiley, 2000, ch. XVI.

[11] W. M. J. Batten, A. S. Bahaj, A. F. Molland, J. R. Chaplin, and Sustainable Energy Research Group, "Experimentally validated numerical method for the hydrodynamic design of horizontal axis tidal turbines," Ocean Eng., vol. 34, no. 7, pp. 1013-1020, May 2007.

[12] W. M. J. Batten, A. S. Bahaj, A. F. Molland, and J. R. Chaplin, "Hydrodynamics of marine current turbines," Renewable Energy, vol. 31, no. 2, pp. 249-256, Feb. 2006.

[13] H. Glauert, The Elements of Airfoil and Airscrew Theory, 2nd ed. Cambridge, U.K.: Cambridge Univ. Press, 1959, ch. 3 and 4.

[14] S. Müller, M. Deicke, and R. W. De Doncker, "Doubly fed induction generator systems," IEEE Ind. Appl. Mag., vol. 8, no. 3, pp. 26-33, May-Jun. 2002.

[15] J. M. Carrasco, L. G. Franquelo, J. T. Bialasiewicz, E. Galvan, R. C. P. Guisado, Ma. A. M. Prats, J. I. Leon, and N. Moreno-Alfonso, "Powerelectronic systems for the grid integration of renewable energy sources: A survey," IEEE Trans. Ind. Electron., vol. 53, no. 4, pp. 1002-1016, Jun. 2006.

[16] R. Pena, R. Cerdenas, J. Proboste, G. Asher, and J. Clare, "Sensorless control of doubly-fed induction generators using a rotor-currentbased MRAS observer," IEEE Trans. Ind. Electron., vol. 55, no. 1, pp. 330-339, Jan. 2008.

[17] A. K. Jain and V. T. Ranganathan, "Wound rotor induction generator with sensorless control and integrated active filter for feeding nonlinear loads in a stand-alone grid," IEEE Trans. Ind. Electron., vol. 55, no. 1, pp. 330-339, Jan. 2008.

[18] F. Bonnet, P.-E. Vidal, and M. Pietrzak-David, "Dual direct torque control of doubly fed induction machine," IEEE Trans. Ind. Electron., vol. 54, no. 5, pp. 2482-2490, Oct. 2007.

[19] G. Iwanski and W. Koczara, "Sensorless direct voltage control of the stand-alone slip-ring induction generator," IEEE Trans. Ind. Electron., vol. 54, no. 2, pp. 1237-1239, Apr. 2007.

[20] G. Tapia, A. Tapia, and J. X. Ostolaza, "Proportional-integral regulator-based approach to wind farm reactive power management for secondary voltage control," IEEE Trans. Energy Convers., vol. 22, no. 2, pp. 488-498, Jun. 2007.

[21] L. Xu and P. Cartwright, "Direct active and reactive power control of DFIG for wind energy generation," IEEE Trans. Energy Convers., vol. 21, no. 3, pp. 750-758, Sep. 2006.

[22] R. Cardenas, R. Pena, J. Proboste, G. Asher, and J. Clare, "MRAS observer for sensorless control of standalone doubly fed induction generators," IEEE Trans. Energy Convers., vol. 20, no. 4, pp. 710-718, Dec. 2005.

[23] A. Mirecki, X. Roboam, and F. Richardeau, "Architecture complexity and energy efficiency of small wind turbines," IEEE Trans. Ind. Electron., vol. 54, 1, no. 1, pp. 660-670, Feb. 2007.

[24] M. M. Hand, K. E. Johnson, L. J. Fingersh, and A. D. Wright, "Advanced control design and field testing for wind turbines," Nat. Renewable Energy Lab. (NREL), NREL/CP-500-36118, 2004.

[25] Y. D. Song, B. Dhinakaran, and X. Y. Bao, "Variable speed control of wind turbines using nonlinear and adaptive algorithms," J. Wind Eng. Ind. Aerodyn., vol. 85, no. 3, pp. 293-308, Apr. 24, 2000. 
[26] K. D. Young, V. I. Utkin, and U. Ozguner, “A control engineer's guide to sliding mode control," IEEE Trans. Control Syst. Technol., vol. 7, no. 3, pp. 328-342, May 1999.

[27] B. Beltran, T. Ahmed-Ali, and M. El Hachemi Benbouzid, "Sliding mode power control of variable-speed wind energy conversion systems," IEEE Trans. Energy Convers., vol. 23, no. 2, pp. 551-558, Jun. 2008.

[28] D. Xiang, R. Li, P. J. Tavner, and S. Yang, "Control of a doubly fed induction generator in a wind turbine during grid fault ride-through," IEEE Trans. Energy Convers., vol. 21, no. 3, pp. 652-662, Sep. 2006.

[29] S. E. Ben Elghali, M. E. H. Benbouzid, J. F. Charpentier, T. AhmedAli, J. M. Gahery, and A. Denis, "Modeling and MPPT sensorless control of a DFIG-based marine current turbine," in Proc. Int. Conf. Electr. Mach., Vilamoura, Portugal, Sep. 2008, DOI: 10.1109/ICELMACH.2008.4800165.

[30] X. Yu and O. Kaynak, "Sliding-mode control with soft computing: A survey," IEEE Trans. Ind. Electron., vol. 56, no. 9, pp. 3275-3285, Sep. 2009.

[31] J. J. E. Slotine, "Sliding controller design for nonlinear systems," Int. J. Control, vol. 40, no. 2, pp. 421-434, Aug. 1984.

[32] A. Levant and L. Alelishvili, "Integral high-order sliding modes," IEEE Trans. Autom. Control, vol. 52, no. 7, pp. 1278-1282, Jul. 2007.

[33] L. Fridman and A. Levant, Sliding Mode Control in Engineering. New York: Marcel Dekker, 2002, ch. 3, pp. 53-101.

[34] E. Koutroulis and K. Kalaitzakis, "Design of a maximum power tracking system for wind-energy-conversion applications," IEEE Trans. Ind. Electron., vol. 53, no. 2, pp. 486-494, Apr. 2006.

[35] H. K. Khalil, Nonlinear Systems. New York: McMillan, 1992, ch. 14.

[36] "The exploitation of tidal marine currents," EU Commission, Rep. EUR16683EN, 1996.

[37] S. E. Ben Elghali, R. Balme, K. Le Saux, M. E. H. Benbouzid, J. F. Charpentier, and F. Hauville, "A simulation model for the evaluation of the electrical power potential harnessed by a marine current turbine," IEEE J. Ocean. Eng., vol. 32, no. 4, pp. 786-797, Oct. 2007.

[38] A. S. Bahaj, A. F. Molland, J. R. Chaplin, and W. M. J. Batten, "Power and thrust measurements of marine current turbines under various hydrodynamic flow conditions in a cavitation tunnel and a towing tank," Renewable Energy, vol. 32, no. 3, pp. 407-426, Mar. 2007.

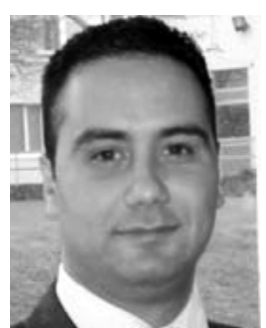

Seif Eddine Ben Elghali (S'04) was born in Téboulba, Tunisia, in 1981. He received the B.Sc. degree in electrical engineering from ENIT, Tunis, Tunisia, in 2005, the M.Sc. degree in automatic control from the University of Poitiers, Poitiers, France, in 2006, and the Ph.D. degree in electrical engineering from the University of Brest, Brest, France in 2009.

After receiving the $\mathrm{Ph} . \mathrm{D}$. degree, he joined the French Naval Academy, Brest, France as a Teaching and Research Assistant. His current research interests include modeling and control of renewable energy applications.

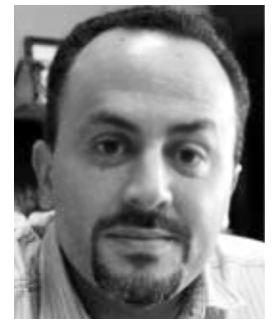

Mohamed El Hachemi Benbouzid (S'92-M'95SM'98) was born in Batna, Algeria, in 1968. He received the B.Sc. degree in electrical engineering from the University of Batna, Batna, Algeria, in 1990, the M.Sc. and Ph.D. degrees in electrical and computer engineering from the National Polytechnic Institute of Grenoble, Grenoble, France, in 1991 and 1994, respectively, and the Habilitation à Diriger des Recherches degree from the University of Picardie "Jules Verne," Amiens, France, in 2000.

After receiving the Ph.D. degree, he joined the Institut Universitaire Professionnalisé of Amiens, University of Picardie "Jules Verne," Amiens, France, where he was an Associate Professor of Electrical and Computer Engineering. Since September 2004, he has been with the Institut Universitaire de Technologie of Brest, University of Brest, Brest, France, where he is a Professor of Electrical Engineering. His main research interests and experience include analysis, design, and control of electric machines, variable-speed drives for traction, propulsion, and renewable energy applications, and fault diagnosis of electric machines.

Prof. Benbouzid is a Senior Member of the IEEE Power Engineering, Industrial Electronics, Industry Applications, Power Electronics, and Vehicular Technology Societies. He is an Associate Editor of the IEEE TRANSACTIONS ON ENERGY CONVERSION, the IEEE TRANSACTIONS ON INDUSTRIAL ELECTRONICS, the IEEE TRANSACtions on Vehicular TeChNOLOGY, and the IEEE/ASME TRANSACTIONS ON MECHATRONICS.

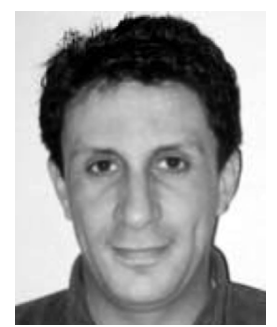

Tarek Ahmed-Ali was born in Algiers, Algeria, in 1972. He received the B.Sc. degree in electrical engineering from the Ecole Nationale Polytechnique of Algiers, Algiers, Algeria, in 1994, the M.Sc. degree in electrical and computer engineering from University of Paris VI, Paris, France, in 1995, and the Ph.D. degree in electrical and computer engineering from the University of Paris Sud, Paris, France, in 1998.

In 1998, he joined the University of Paris XIII, Paris, France as a Teaching and Research Assistant. In 1998, he moved to Ecole Centrale de Lille, Lille, France, also as a Teaching and Research Assistant. In 2000, he was appointed Research and Development Engineer at SNCF (the French Railway Corporation). In 2002, he was appointed to a lectureship in Control Engineering at Ecole Nationale des Ingénieurs des Etudes et Techniques de l'Armement of Brest (ENSIETA), Brest, France. In 2008, he was appointed Associate Professor of Automatic Control at the University of Caen, Caen, France. His main research interests are sliding mode control, nonlinear observers, and fault-tolerant control and diagnosis in the field of alternating current (ac) drives.

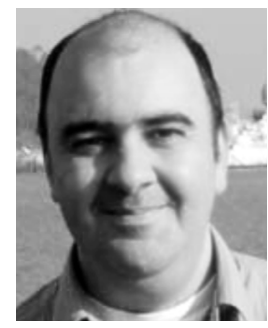

Jean Frédéric Charpentier (M'02) was born in Tananarive, Madagascar, in 1969. He received the M.Sc. and Ph.D. degrees in electrical engineering from the National Polytechnic Institute of Toulouse, Toulouse, France, in 1993 and 1996, respectively.

From 1996 to 1997, he was a Postdoctoral Fellow at Laval University, Québec City, QC, Canada. From 1997 to 2002, he was an Assistant Professor at the Institut Universitaire de Technologie of Brest, University of Brest, Brest, France. Since 2002, he has been an Associate Professor in the French Naval Academy, Brest, France. His current research interests include design aspects on electrical machines and drives, electrical naval propulsion systems, and marine renewable energy. 